\title{
Benefits of adapting to sea level rise: the importance of ecosystem services in the French Mediterranean
} sandy coastline

Cécile Hérivaux, BRGM, Univ Montpellier, 1039 rue de Pinville, 34000 Montpellier, France, c.herivaux@brgm.fr Hélène Rey-Valette, LAMETA, Univ Montpellier, helene.rey-valette@univ-montp1.fr

Bénédicte Rulleau, IRSTEA, benedicte.rulleau@irstea.fr

Anne-Laurence Agenais, BRGM, Univ Montpellier, ESPELIA, anne-laurence.agenais@espelia.fr

Marianne Grisel, ARTELIA Water \& Environment, Marianne.GRISEL@arteliagroup.com

Laure Kuhfuss, LAMETA, Univ Montpellier, SGSD, Univ of St Andrews, 1k38@st-andrews.ac.uk

Laure Maton, BRGM, Univ Montpellier, 1.maton@montpellier3m.fr

Charlotte Vinchon, BRGM, c.vinchon@brgm.fr

\section{Abstract}

This article proposes an innovative approach to assess the benefits of adapting to sea level rise (SLR) in a coastal area on a regional scale. The valuation framework integrates coastal ecosystem services, together with urban and agricultural assets. We simulate the impacts of a progressive $1 \mathrm{~m}$ rise in sea level in the $21^{\text {st }}$ century and an extreme flooding event in 2100 for four contrasted adaptation scenarios (Denial, "Laissez-faire”, Protection and Retreat). The assessment involves coupling the results of hazard-modelling approaches with different economic valuation methods, including direct damage functions and methods used in environmental economics. The framework is applied to the French Mediterranean sandy coastline. SLR will result in major land-use changes at the 2100 time horizon: relocation or densification of urban areas, loss of agricultural land, increase in lagoon areas and modification of wetlands (losses, migration or extension of ecosystems). Total benefits of public adaptation options planned in advance could reach $€ 31.2$ billion for the period $2010-2100$, i.e. $€ 69,000$ per inhabitant (in the study area) in 2010 or $€ 135 \mathrm{million} / \mathrm{km}$ of coastline. Our results highlight the importance of (i) raising awareness to ensure that public services and coastal managers can anticipate the consequences of SLR and (ii) incorporating coastal ecosystems into the assessment of the adaptation options. Our findings could provide a basis for participatory foresight approaches to build coastline adaptation pathways.

Keywords: sea level rise; ecosystem services; adaptation options; climate change; economic valuation 


\section{INTRODUCTION}

Coastal systems and low-lying areas will be increasingly at risk from flooding in the 21 st century as a result of a progressive sea level rise (SLR) and extreme flooding (Wong et al. 2014). Assessing the vulnerability of coastal zones to SLR has become an increasingly important field of research since the 1980s. Yohe (1990) and Titus (1990) were among the first to analyse the consequences of this phenomenon. They investigated the economic vulnerability of coastal areas to a 0.5 to $2 \mathrm{~m}$ SLR at the scale of the United States.

Since then, several types of approaches have been developed at a local and global level. At a local scale, researchers use process-based models and elevation-based GIS analyses to determine the economic impacts of SLR. They focus primarily on the impacts of SLR with regard to the population, infrastructure and buildings in an urban context (Hallegatte et al. 2011; Lichter and Felsenstein 2012; Kebede and Nicholls 2012; Fletcher et al. 2016). Global scale assessments have been conducted using integrated assessment models, such as the DIVA model (Hinkel et al. 2013) or the FUND model (Anthoff et al. 2010). So far, the regional (sub-national) scale has been overlooked. However, on a regional scale, decision-support tools are required to anticipate SLR and ensure that those responsible for land-use and natural resource management can plan adaptation policies.

SLR could impact the coastal area in several ways (Wong et al. 2014). In urban and agricultural areas, SLR may force people to migrate. It may cause loss or damage to crops, land, housing and buildings. In addition, SLR may have an impact on ecosystems, such as beach loss, lagoon extension, wetland migration and groundwater salinisation. The economic impact of SLR generally focuses on urban and agricultural areas. Little research has been done to assess the economic impacts of SLR on ecosystems. In general, existing studies focus on characterising the physical impacts of SLR with regard to a particular coastal ecosystem (see for instance: Monioudi et al. 2014 for beaches; Craft et al. 2009 for wetlands; Li et al. 2015 for mangroves), without considering the associated economic impacts. Failure to take account of the economic impact means that the latter cannot be put into perspective with other expected impacts. However, coastal ecosystems are essential components of coastal areas. By providing a variety of ecosystem services, they make a significant contribution to the welfare of residents, tourists and day trippers (MEA 2005). The loss or transformation of coastal ecosystems resulting from SLR could affect ecosystem services and, therefore, have an impact on human well-being. As underlined by Lin et al. (2014) "any assessment that incorporates only goods with market proxies (such as property, human health, or economic production) risks seriously underestimating both the costs and the benefits of the adaptation options". Thus, analysing the impacts of SLR on coastal ecosystems and the services they provide could be beneficial for coastal managers when it comes to raising awareness about the need to anticipate SLR and choose the best strategy for 
adaptation. Overall, the IPCC (Wong et al. 2014) claims that the economics of coastal adaptation are underresearched and that more comprehensive assessments are needed for the valuation of coastal ecosystem services. In this perspective, the article aims to provide a comprehensive assessment of the benefits of adapting to SLR at a regional scale. It proposes an innovative approach that integrates coastal ecosystem services, as well as urban and agricultural assets, within the valuation framework. We simulate the impacts of a gradual $1 \mathrm{~m}$ rise in sea level over the $21^{\text {st }}$ century and an extreme flooding event in 2100 for four contrasted adaptation scenarios (Denial, "Laissezfaire", Protection and Retreat). We study the gradual impacts of loss of land and land-use changes, and other impacts due to SLR such as saltwater intrusion. The assessment involves coupling the results of hazard-modelling approaches with various economic valuation methods, including direct damage functions and valuation methods used in environmental economics. Our objective is to estimate the potential benefits of adapting to SLR to help decision makers discussing the possible consequences of the different adaptation options.

\section{SLR AND ADAPTATION OPTIONS FOR THE FRENCH MEDITERRANEAN SANDY COASTLINE}

\subsection{The French Mediterranean sandy coastline}

The scope of our research covers the Languedoc-Roussillon coastline, which extends over $231 \mathrm{~km}$ and mainly consists of a low-lying sandy coast (Figure 1). Population growth in the Languedoc-Roussillon administrative region is among the highest in France, with an annual increase of 33,000 inhabitants since 1999. Over and above the major cities (such as Montpellier, Nimes and Perpignan), population density is particularly high along the coast. Urban development along the coastline began in the 1960s, with the creation of tourist sea resorts. Coastal risks were largely overlooked. The region is one of the most popular tourist destinations in France. In 2014, 8.5 million tourists visited the region (CCI Languedoc-Roussillon), generating $€ 7$ billion from tourism, i.e. $13 \%$ of regional GDP (INSEE).

Currently, sandy beaches make up 70\% of the coastline and alternate with built-up areas. Regional Mediterranean wetlands represent 17\% of all French wetlands of international importance (CGDD 2010). Almost all of them are community interest habitats under the European Habitats Directive and belong to the Natura 2000 network. Six aquifers located in the coastal area are of regional importance, representing 100 million cubic metres of groundwater, which provides $32 \%$ of the regional drinking-water supply (AERMC). Agricultural land accounts 
1

2 grassland and rice.

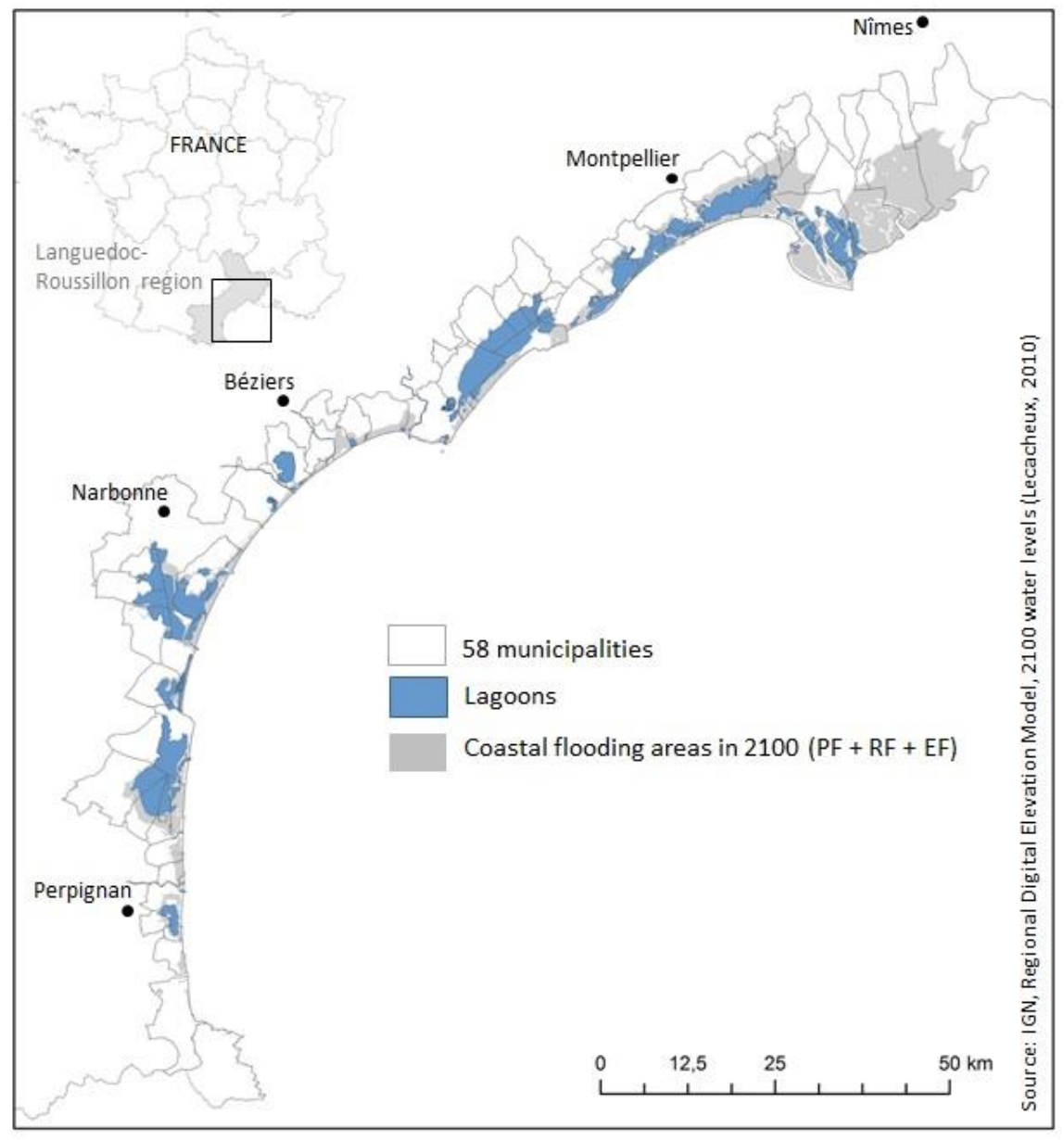

Fig. 1 Study area

The coast is already subject to marine flooding, especially during the winter season. For instance, the winter storm of 1982 generated a 1.7 m storm surge in the municipality of Palavas-les-Flots, where the mean ground elevation is $0.3 \mathrm{~m}$. The storm caused 15 casualties and damaged buildings and marinas. At the regional scale, the direct costs of damage to non-insured assets alone amounted to $€ 18$ million. Sandy beaches are also subject to erosion. Since the 1960s, robust coastal protection works (mostly groynes and breakwaters) have gradually been built along the sandy shoreline, particularly in urban and tourist areas. In 2010, 285 coastal protection works were recorded in the study area (Vanroye and Auffret 2010). Over the last 20 years, strategies for coastal protection have evolved from these "hard" engineering techniques to much "softer" approaches (beach nourishment). According to Vanroye and Auffret (2010), the 1948-2010 cumulative cost for fighting erosion amounts to $€ 117$ million.

\footnotetext{
${ }^{1}$ http://www.siglr.org/
} 


\subsection{Impacts of SLR on coastal flooding areas}

Climate change and a gradual SLR are expected to increase these expenses due to marine flooding in the coming decades. Adapting the IPCC (Wong et al. 2014) hypotheses to the case of the Languedoc-Roussillon gives a worstcase scenario, with a $1 \mathrm{~m}$ rise in sea level by 2100 and greater storm impact due to higher water levels. Figure 2 presents the expected change in water levels for three return periods in relation to coastal flooding (Lecacheux et al. 2010): (i) permanent flooding (PF) (area flooded $100 \%$ of the time), which corresponds to the mean meteorological conditions and the lowest astronomical tides; (ii) recurrent flooding (RF) (area flooded at least twice a year), which corresponds to the mean annual meteorological conditions and the highest astronomical tides; and (iii) extreme flooding (EF), which corresponds to a 100-year return period for a winter storm surge (the winter 1982 storm is used as the reference).

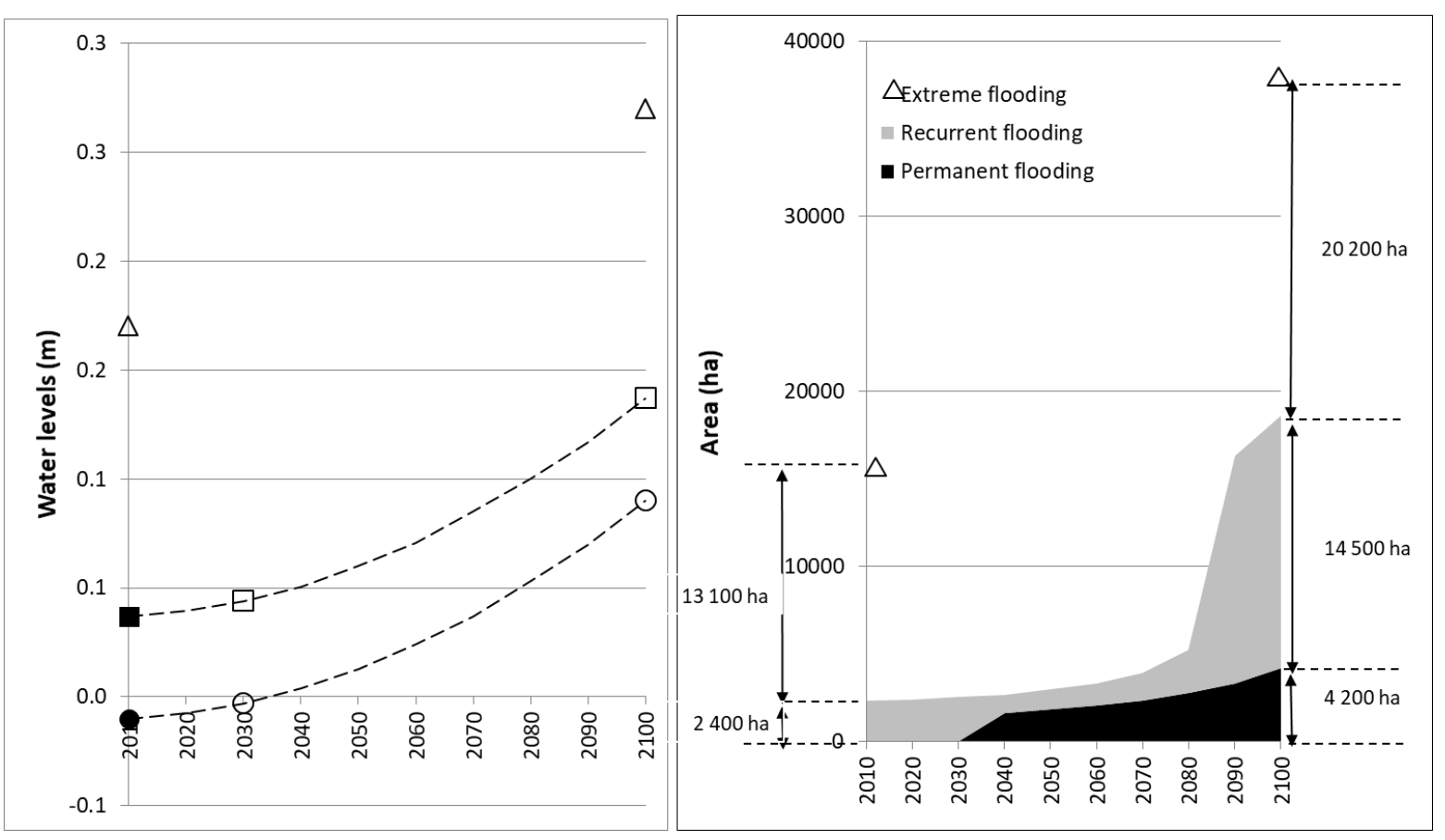

Fig. 2 Evolution of (a) water levels and (b) coastal flooding area resulting from PF, RF and EF over time.

$$
\text { Legend (a): observed }(\bullet) \text { and simulated }(O) \text { permanent water level; observed }(\square) \text { and simulated }(\square) \text { recurrent }
$$
water level; average simulated extreme water level $(\Delta)$; --- extrapolation of permanent and recurrent water levels over time (polynomial trend curve).

Crossing simulated water levels with the regional Digital Elevation Model (Lecacheux et al., 2010) shows that the coastal areas affected by SLR will increase slowly until 2080. From then on, the rate of increase is expected to accelerate because of the topography of the study area. The coastal areas affected by PF or RF are likely to increase by a factor of 3.5 between 2080 and 2100 (Figure 2). In 2100, 58 coastal municipalities (Figure 1) may be exposed to coastal flooding, with 18,500 ha flooded by PF or RF (9\% of total area), of which 4,200 ha of land will be 
permanently flooded. Results also show that in 2100 , EF is likely to affect a larger area $(20,200 \mathrm{ha}$, an area $55 \%$ greater). This is quite distinct from the area affected by EF in 2010. Overall, almost 39,000 ha may be exposed to coastal flooding in 2100 compared to 15,000 ha in a situation without SLR.

\subsection{Potential adaptation options}

As a response to these threats, several adaptation options may be envisaged. The IPCC classification of coastal adaptation strategies consisting of retreat, accommodation and protection (Nicholls et al. 2007) is now widely used and applied in both developed and developing countries (Wong et al., 2014). We adapted this classification to integrate the concepts of anticipatory versus reactive, and planned (collective state-regulated) versus individual decision-making (Tompkins, 2008). Options based on individual decision-making come from Yohe et al. (1996) and Michael (2007). On this basis, we frame four contrasted management options:

- Option 1: "Denial" assumes that there is neither anticipation nor adaptation. It is typically characterised by individual reactive decision-making, which corresponds to an option that could also be named "inaction", "worst case" or "no foresight" (Yohe et al. 1996; Michael 2007). In this case, citizens are unaware of the SLR threat because only partial knowledge or information is available. Thus, there is no warning and consequently no structural depreciation of properties.

- Option 2: "Laissez-faire" assumes that there is no collective state-regulated strategy of adaptation. It relies on individual anticipatory decision-making. The threat of SLR is relatively well-known, which means citizens can anticipate. Greater awareness of the threat of SLR is expected to trigger a gradual depreciation in the economic value of housing, businesses and other structures exposed to flooding (Yohe et al.. 1996).

- Option 3: "Protection" assumes planned anticipatory decision-making. It consists of protecting the entire coastline from PF and RF, by implementing a combination of hard engineering techniques (dikes, seawalls) and softer approaches (beach nourishment, dune restoration).

- Option 4: "Retreat" assumes a strategic, anticipatory and planned relocation of structures and activities beyond the area exposed to flooding.

In the last decades, the Protection option was implemented to preserve the Languedoc-Roussillon coastline. Since the adoption in 2012 of the French national strategy of integrated coastline management, the Retreat option is now promoted by the French Environment Ministry (MEDDTL 2002). The progressivity of SLR, the slow increase in areas expected to be flooded by 2080, and the steady decline in public resources (both financial and human) suggest that public authorities will do little in terms of adaptation to the threat of SLR in the near future (Denial and 
"Laissez-faire" options). These options are likely to have a severe impact on future generations over the period 2080-2100. It takes time to implement adaptation strategies for SLR. Raising the awareness of citizens and elected representatives about the benefits of such different options may be helpful to initiate the design of adaptation pathways at the regional level.

\section{METHOD}

\subsection{Overview of the valuation framework}

We propose a valuation framework to assess the benefits of these four contrasted management options. The framework is organised into five main steps (Figure 3):

- Step 1 consists of building narrative scenarios for the coastal area at the 2100 horizon. We consider that the changes affecting the coastal area will predominantly be driven by (i) the evolution in water levels, (ii) the option chosen to adapt to SLR and (iii) population growth (assumed to remain constant in the study area, with a linear increase based on INSEE 1988-2006 statistics). Narrative scenarios were built during a 2-day project meeting $^{2}$ between scientific researchers from a broad range of disciplines (sedimentology, geography, sociology, economics and agronomy). As a result, four adaptation scenarios (one for each of the adaptation options discussed in 2.3), describe the plausible evolutions likely to affect the coastal area. The scenarios make assumptions about the associated land-use changes (Online Resource 2).

- Step 2 provides quantitative estimates of land-use changes for each scenario in the 58 municipalities exposed to coastal flooding. The following categories of land use are considered: urban, agricultural, forest and seminatural, lagoons, wetlands, beaches and dunes. The 2006 regional land cover GIS database SIG-LR ${ }^{3}$, completed by Natura 2000 database, provides the basis for the analysis. Curves depicting the evolution of the coastal flooding area due to PF and RF (Figure 2) are used to quantify the areas gained or lost by each landuse category over time.

- Step 3 consists of understanding the impacts of PF and RF during the 2010-2100 period for each land-use category and adaptation scenario. The impacts are described in terms of (i) damage to assets located in urban and agricultural areas and (ii) changes in the services provided by coastal ecosystems. First, they are characterised in physical terms before being assessed in economic terms. We assume that the number of assets

\footnotetext{
${ }^{2}$ Activity conducted as part of the multidisciplinary MISEEVA research project, funded by the French National Research Agency

${ }^{3}$ http://www.siglr.org/
} 
and the importance of ecosystem services are proportional to the corresponding land-use category. In other words, the impacts can be linked to the area gained or lost due to PF and RF over time.

- Step 4 involves the characterisation of the physical impacts and an economic valuation of an EF event that occurs in 2100. The impact assessment of an EF event in 2100 is based on the EF area with the 2100 projected land use for each scenario and provides a comparison with a situation with no SLR.

- Step 5 assesses the benefits of adapting to SLR. It compares the impacts of progressive SLR and an EF event (in 2100) in the Denial scenario with the three other adaptation scenarios.

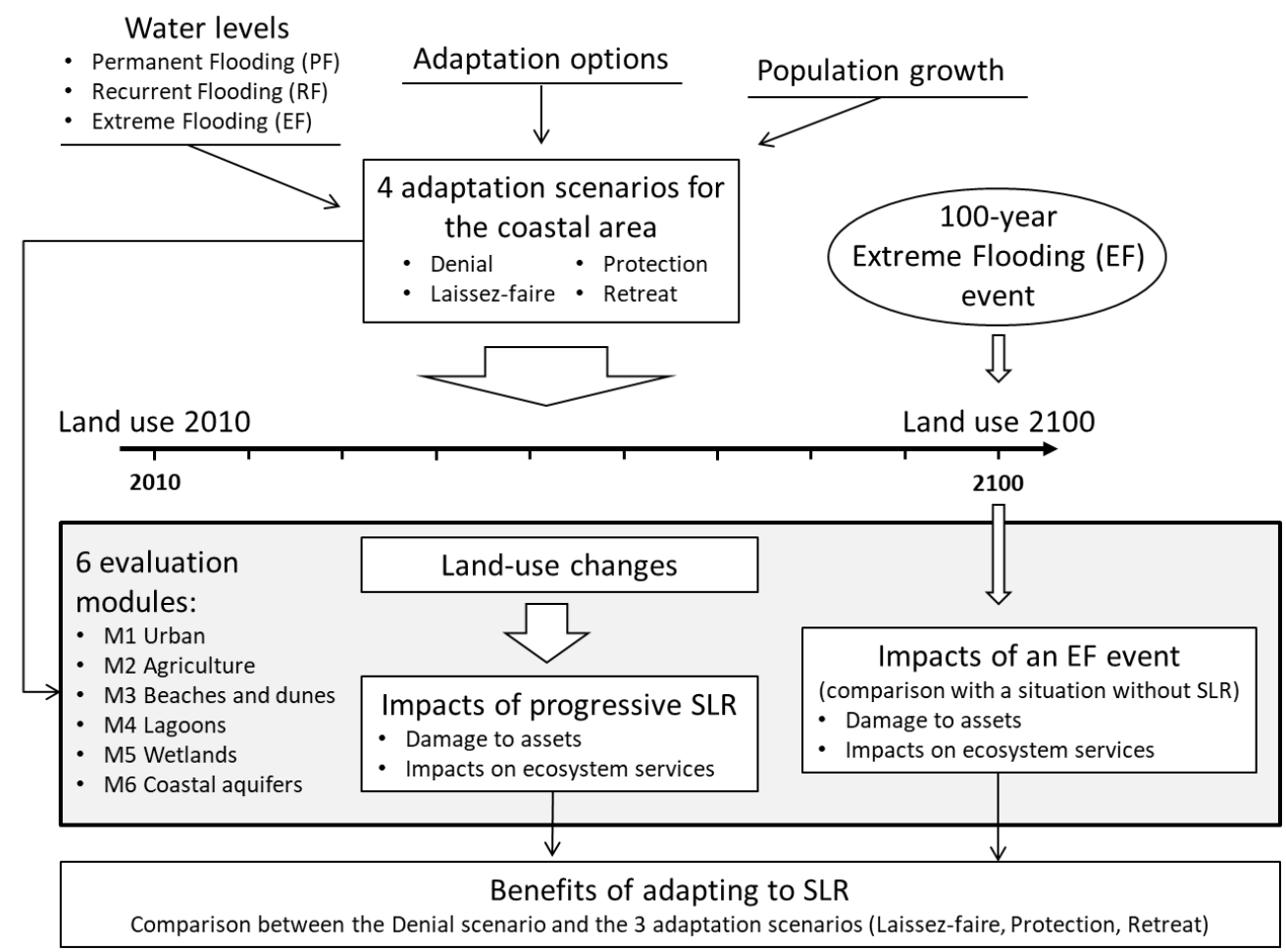

Fig. 3 Diagram describing the valuation framework

Steps 2 to 4 are implemented using six separate evaluation modules (M1 to M6), one for each land-use category and one for coastal aquifers. Each module applies several methodological approaches (Table 1), depending on the type of asset and service. The following sections (3.2 to 3.7) focus on each evaluation module. Further details on materials and methods can be found in Sogreah (2011) for urban areas, Agenais (2010) for agriculture, Rulleau and Rey-Valette (2013) and Rulleau et al. (2015) for beaches and dunes, and Kuhfuss et al. (2016) for lagoons and wetlands. Details on the valuation functions are provided in Online Resource 1.

\subsection{Urban (M1)}

In urban areas, M1 considers that PF and RF will force people to migrate and will cause loss or damage to land, housing and businesses if no protective measures are implemented. The analysis excludes the impacts on 
infrastructure (roads, bridges, railways). It is assumed that progressively flooded urban areas (in the Denial, "Laissez-faire" and Retreat options) are relocated beyond the EF zone, onto predominantly agricultural land in the same municipality, as far as possible. The economic cost of urban land loss is assessed at its opportunity cost, i.e. the value of interior agricultural land (3.3) and not the value of urban coastland (Yohe et al. 1995; Darwin and Tol 2001).

In the case of Denial or "Laissez-faire", PF and RF cause property losses (housing and business premises) because of the failure to protect or displace property prior to flooding. Thus, inhabitants are forced to migrate and relocate. These derelict urban areas become urban wastelands. The difference between the two scenarios lies in the time at which people migrate. The Denial scenario implies that SLR is not anticipated at all: housing and business premises are gradually abandoned because of permanent or recurrent flooding. Impacts are assessed by the replacement cost method on the basis of individual and collective housing values ${ }^{4}$, respectively, and mean building values per size category. However, the "Laissez-faire" scenario considers a market-based adaptation and, as citizens anticipate SLR, housing and business premises are abandoned 10 years before being flooded. In this case, the number of people that migrate is slightly lower than in the Denial scenario (10 years population growth will occur outside the area at risk of flooding) and properties depreciate in value as a result of anticipation. We consider that knowing that the property will be flooded at a 10-years horizon implies an accelerated rate of financial depreciation of the capital asset located in a future flooded area. Expert judgment estimates that only $30 \%$ of the financial value of housing and businesses would remain. Negative amenities resulting from urban wasteland are not accounted for. In the Retreat scenario, abandoned urban areas are assumed to be dismantled and people also migrate ten years before being flooded. In the Protection scenario, it is presumed that urban areas are fully protected and, therefore, the population density increases. In both cases, permanent and recurrent coastal flooding causes no damage to housing and business premises.

M1 assesses the impacts of an EF event in 2100 in terms of the number of people that may be affected and the damage to ground-floor housing and businesses. Impacts on infrastructure are not accounted for. Impacts are assessed using the damage functions developed in the French context. For ground-floor housing, impacts are estimated as a percentage of the property value. The percentage is a function of the water level in the building (Torterotot 1993). Damage functions of IIBRBS (1998) are used to assess the impacts on buildings used for professional purposes. A distinction is made between damage to equipment and stock, structural degradation and operational losses.

\footnotetext{
${ }^{4}$ immobilier.com and terrain-construction.com consulted in March 2011
} 


\subsection{Agriculture (M2)}

$\mathrm{PF}$ and RF are assumed to cause losses in agricultural land in the Denial, "Laissez-faire" and Retreat scenarios because farmland is submerged and transformed into wetlands, lagoons or marine ecosystems. Additional losses of agricultural land are expected due to (i) the relocation of urban areas that are flooded (3.2) and (ii) the migration of beaches and dunes, which encroach on agricultural land (3.4).

Economic impacts can be expressed as the sum of annual cropland rents between the year of flooding and 2100 (Fankhauser 1994). The mean agricultural land values per municipality are based on the figures for 2010 (2010 AGRESTE and SAFER databases: from $€ 3,570$ to $€ 24,850$ /ha with an average of $€ 9,700 /$ ha) and a $10 \%$ return rate.

An EF event in 2100 may have several impacts on crops. Classic damage functions (Devaux-Ros 2000; SYMADREM 2010; Deleuze et al. 1991), which are generally used to assess the impact of floods on agricultural land, are adapted to integrate the additional impacts of salt on crops and soil (Agenais, 2010), on the basis of interviews with agricultural experts in the Languedoc-Roussillon region and in the Western France, which was affected by the storm, Xynthia, in February 2010. Damage functions distinguish (i) yield losses, (ii) rehabilitation tasks and (iii) damage to equipment. First, the value of yield losses is estimated as a percentage of revenue and operating costs per crop type (Chamber of Agriculture databases). Revenue is a function of yield (2008 AGRESTE database) and market price (2010 agricultural compensation grid, in the case of the natural disasters dataset). The percentage of losses is a function of crop type, soil type and the intensity of EF. Second, the costs of rehabilitation tasks are estimated as a function of the number of working hours. This depends on the crop type and the quantity of gypsum necessary to rehabilitate the agricultural land, which in turn depends on crop and soil types. Finally, the damage to equipment is estimated as a percentage of equipment values. This percentage is a function of the crop type, soil type and intensity of EF.

\subsection{Beaches and dunes (M3)}

Beaches and dunes are predominantly threatened by $\mathrm{PF}^{5}$. This is particularly the case in the urban context, where the coastal squeeze phenomenon may occur (Luisetti et al. 2008). As the sea level rises, the permanent infrastructure and buildings prevent the beaches and dunes from retreating. Where possible, beaches and dunes will migrate inland, encroaching on agricultural and natural areas. Major beach and dune losses are expected in

\footnotetext{
${ }^{5}$ While RF and EF may also impact beaches and dunes by increasing erosion rates, data and knowledge were insufficient to build plausible assumptions for the evolution in erosion over the next few decades.
} 
the Denial and "Laissez-faire" because urban assets remain (forming urban wasteland) after people have been forced to migrate inland. In the Denial scenario beach losses are only considered to be due to marine flooding because it is assumed that the towns and cities continue to implement traditional protection measures against erosion. In the "Laissez-faire" scenario, the state does not intervene further to limit beach losses. Therefore, additional beach losses due to erosion are expected (Rulleau et al. 2015). In the Denial and "Laissez-Faire" scenarios, the estimated area of beaches and dunes likely to disappear over time is calculated by crossing the PF water level with the regional high resolution Digital Elevation Model (LIDAR), the type of land use inland of the beach (urban, agricultural, natural) and the historic erosion/accretion rate (Brunel 2010). No loss of beaches or dunes is anticipated in the Protection scenario (we assume large-scale beach nourishment) or in the Retreat scenario (their evolution is assumed to be unconstrained).

The loss of beaches and dunes will inevitably affect the ecosystem services that they provide to society. This paper focuses on two services: storm protection and recreation. Associated values are based on the results of a contingent valuation survey conducted in 2009 in a pilot area of $12 \mathrm{~km}$, located south of Montpellier. The area chosen is representative of urban and natural beaches along the Languedoc-Roussillon coastline. The storm protection service is estimated by Rulleau et al. (2015) at $€ 229 /$ household/year, which is equivalent to $€ 4,588 /$ household over a 20 -year period. The recreation service is estimated at $€ 36 /$ household/year by Rulleau and Rey-Valette (2013), the equivalent of $€ 728 /$ household over a 20 -year period. These values are then aggregated for the entire coastal area in the region with the total number of permanent and second homeowners (312,300 households) and the total number of permanent and seasonal residents, tourists and day trippers (3,360,000 households), divided by the total area of beaches and dunes likely to disappear. The calculation provides a value per hectare.

\subsection{Lagoons (M4)}

A rise in water levels may lead to lagoon expansion and a change in salinity (UNEP-MAP and RAC/SPA 2010), except for the Protection ${ }^{6,7}$ scenario. Above all, these changes are likely to have an impact on water purification services $^{8}$. Lagoons play a key role in diluting nitrogen $(\mathrm{N})$ and phosphorus $(\mathrm{P})$, originating from the watersheds located upstream. Shellfish growers, fishermen, swimmers and other recreational users may be affected by $\mathrm{N}$ and $\mathrm{P}$ if their concentrations are too high (above a threshold concentration) and lead to eutrophication phenomena. In a report to the European Commission, Ifremer (2001) defines five levels of eutrophication, the first and lowest

\footnotetext{
${ }^{6}$ Under the Protection scenario, lagoon and wetland ecosystems are assumed to remain stable (Online Resource 2).

${ }^{7}$ Impacts of an EF event are not included in the analysis, they are considered to be negligible in comparison with PF and RF impacts because coastal wetland and lagoon ecosystems are resilient to EF.
} 
being 'no human impact on the level of eutrophication' to the fifth and highest being 'highly degraded by eutrophication'. We use the total Nitrate and Phosphorus concentration limits between the second and third level, where anoxic crises become recurrent instead of exceptional, as the threshold from which the impact of eutrophication is significant on users. Lagoon expansion will increase the volume of water, which may increase its capacity to dilute $\mathrm{N}$ and $\mathrm{P}$. An increase in the volume of water is assessed as a function of the PF water level, lagoon depth and the historic siltation rate (Castaing 2008). N and P concentrations are assessed for each lagoon, with estimates of $\mathrm{N}$ and $\mathrm{P}$ fluxes that originate from the upstream watershed (local databases). Concentrations exceed threshold values $(75 \mu \mathrm{mol} \mathrm{N} / \mathrm{L}$ and $1.5 \mu \mathrm{mol} \mathrm{P} / \mathrm{L}$ ) for five lagoons. For these lagoons, the additional $\mathrm{N}$ and P fluxes that could be diluted by the increase in the lagoon volume are quantified and expressed in population equivalent (p.e.).

Associated economic values are estimated using the replacement cost method, based on the assumption that a treatment station would have to be built if this service did not exist. Investment costs range from $€ 220$ to $€ 610 /$ p.e.N and from $€ 310$ to $€ 980 /$ p.e.P as a function of the size of the station and a lifetime of 25 years, i.e. a mean annual cost of $€ 9.4 /$ p.e.N and $€ 13.5 /$ p.e.P (CGDD 2010).

\subsection{Wetlands (M5)}

$\mathrm{PF}$ and $\mathrm{RF}^{6,7}$ are expected to have different impacts on wetlands. PF wetlands are assumed to become marine or lagoon ecosystems. RF is likely to cause habitat transformation and/or migration, depending on how far the habitats are from the lagoon saltwater table (Kuhfuss et al. 2016). Similarly to beaches and dunes, in the case of the Denial and "Laissez-faire" scenarios, wetlands can only migrate onto flooded undeveloped areas (natural and agricultural land). In the Retreat scenario, wetlands can also shift onto adjacent former urban areas.

Wetlands are important for their biodiversity. Over 40 Natura 2000 habitats are represented in the study area. By crossing PF and RF maps with regional land use (SIG-LR 2006) and habitat types (Natura 2000 cartographic data), we identified 10 significant wetland habitats, which may be impacted (see Kuhfuss et al., 2016 for more details on these wetland habitats). This represents $78 \%$ of the regional wetland areas. This habitat classification provides the basis for the analysis conducted in M5. The services provided by each significant habitat are identified, according to the Millennium Ecosystem Assessment typology (MEA, 2005) and the Natura 2000 inventory. The habitat classification is then used to examine the losses and transformations of ecological habitats for each adaptation 
1

scenario, depending on the distance from the saltwater table (which, in turn, depends on elevation) ${ }^{8}$. Finally, the impact valuation is based on an analysis of the changes in the services provided by the wetlands as a result of habitat transformation. This paper considers two provisioning services (grazing and materials) and two regulating services (flood protection and water purification).

The values for provisioning services are estimated using market prices: the grazing service is valued as the mean gross margin for local pasture ( $€ 14 /$ ha/year); materials provided (reeds) are valued at their local mean gross margin ( $€ 116 / \mathrm{ha} /$ year). Regulating services are valued in terms of benefit transfer using values from a meta-analysis of 89 wetland valuation studies (CGDD 2010): €438/ha/year for the flood protection service and $€ 272 /$ ha/year for the water purification service.

\subsection{Coastal aquifers (M6)}

SLR threatens coastal aquifers with saltwater intrusion. Two hydrogeologists in the region were consulted on the construction of a plausible scenario for saltwater intrusion in coastal aquifers at the 2100 time horizon. Two types of processes are considered:

(i) The brackish zone between fresh and saline groundwater ("saltwater wedge") may shift further inland as a result of PF and RF. Abstraction wells, previously located beyond the saline groundwater wedge zone, will then be situated in areas where upconing of the saline groundwater surface can easily occur (Oude Essink 2001). The shift of the saltwater wedge is characterised as a function of the SLR using the Ghyben and Drabbe (1889) and Herzberg (1901) relationships for the five unconfined coastal aquifers (four alluvial and one calcareous) located in the study area. Retreat and Protection options are not expected to impact the shift of the saltwater wedge;

(ii) Poorly protected abstraction wells will be exposed to the three types of coastal flooding (PF, RF and $\mathrm{EF}$ ) and will allow saline water to percolate towards the aquifers. The groundwater wells that supply drinking water located in the PF and RF flooding areas are assumed to be relocated inland in the Retreat option and protected from PF and RF in the Protection scenario. However, the wells remain exposed to EF, regardless of the adaptation option.

In a context of water scarcity, like that of the Languedoc-Roussillon region, and with an expected increase in water demand in the near future (linked to the increase in population), saltwater intrusion would reduce the freshwater

\footnotetext{
${ }^{8}$ The characterisation of physical impacts is based on interviews and working sessions with the stakeholders and scientific researchers actively involved in managing the lagoons and associated wetlands in the study area.
} 
resources. This could affect provisioning services, such as the public water supply, water for irrigation and industrial uses. We focus our analysis on the public water supply, given that it is the principal use of groundwater in the coastal area. The replacement cost method is used to estimate the values associated with both types of processes for all three flooding categories. Calculations are based on the assumption that small desalination plants are installed to offset the decrease in fresh groundwater availability, with mean annual costs (including investment, operating costs and the environmental costs of $\mathrm{CO} 2$ emissions) ranging from $€ 1.2$ to $€ 1.4 / \mathrm{m} 3$ (based on the analysis of the Worldwide Desalting Plants Inventory database provided by Zhou and Tol 2005).

\section{RESULTS}

First, a progressive SLR may lead to major land-use changes at the 2100 time horizon (except for the Protection scenario): the relocation or densification of urban areas, loss of agricultural land (-8,850 ha, equivalent to $-10 \%)$, the increase in lagoon areas $(+1,730 \mathrm{ha}$, a $5 \%$ rise) and the modification of wetlands (losses, migration or extension of ecosystems). Transition matrices (Table 2) present the type and magnitude of the changes for each scenario. They detail the evolution of each land-use type between 2010 and 2100. For instance, Table (a) illustrates that in the Denial scenario, $90 \%$ of the agricultural land remains agricultural; $3 \%$ is urbanised, $1 \%$ is replaced by beaches and dunes, $5 \%$ becomes wetlands and $1 \%$ is transformed into marine ecosystems. In 2100 , agricultural areas occupy 91,050 ha or $10 \%$ less than in 2010. Overall, Denial and "Laissez-faire" scenarios lead to similar land-use changes, with the creation of 3,050 ha of urban wasteland and 3,500 ha of wetlands (a rise of 19\%) and the loss of 360 to 570 ha $(-11 \%$ to $-17 \%)$ of beaches and dunes due to coastal squeeze. In the case of the Retreat scenario, abandoned urban areas are assumed to be dismantled, beaches and dunes evolve freely and wetlands expand $(+5,640$ ha, a rise of $30 \%)$. 
Table 1. Methods for the quantification and monetary valuation of impacts due to progressive PF and RF, and to an EF in 2100

\begin{tabular}{|c|c|c|c|c|}
\hline & Valuation module & Assets/ services & Impacts & Monetary valuation method \\
\hline \multirow{12}{*}{$\begin{array}{l}\text { Progressive } \\
\text { PF and RF }\end{array}$} & \multirow[t]{3}{*}{ M1: Urban } & Population & People forced to migrate/ to relocate & Not assessed \\
\hline & & Housing & Property losses & Replacement costs \\
\hline & & Businesses & Building losses & Replacement costs \\
\hline & M2: Agriculture & Land & Land loss & Opportunity costs \\
\hline & \multirow[t]{2}{*}{ M3: Beaches and dunes } & Storm protection & Decrease in the service due to beach and dune losses & $\begin{array}{l}\text { Contingent valuation, value transfer } \\
\text { and aggregation }\end{array}$ \\
\hline & & Recreation & Decrease in the service due to beach and dune losses & $\begin{array}{l}\text { Contingent valuation, value transfer } \\
\text { and aggregation }\end{array}$ \\
\hline & M4: Lagoons & Water purification & Improvement in nitrogen $(\mathrm{N})$ and phosphorus $(\mathrm{P})$ dilution capacity & Replacement costs \\
\hline & \multirow[t]{4}{*}{ M5: Wetlands } & Pastures & \multirow[t]{4}{*}{ Increase/ decrease in the services due to wetland gains/ losses } & Market price \\
\hline & & Reeds & & Market price \\
\hline & & Flood protection & & Value transfer \\
\hline & & Water purification & & Value transfer \\
\hline & M6: Coastal aquifers & $\begin{array}{l}\text { Drinking water } \\
\text { provision }\end{array}$ & Decrease in the service due to groundwater salinisation & Replacement costs \\
\hline \multirow[t]{9}{*}{ EF in 2100} & \multirow[t]{5}{*}{ M1: Urban } & \multirow[t]{2}{*}{ Population } & $\begin{array}{l}\text { Full-time inhabitants affected (people living in ground-floor } \\
\text { accommodation) }\end{array}$ & Not assessed \\
\hline & & & Secondary inhabitants affected & Not assessed \\
\hline & & \multirow[t]{3}{*}{ Firms } & Damage to equipment and stocks & \multirow[t]{3}{*}{ Damage functions } \\
\hline & & & Structural degradation & \\
\hline & & & Operating losses & \\
\hline & \multirow[t]{3}{*}{ M2: Agriculture } & \multirow{3}{*}{$\begin{array}{l}\text { Crops and } \\
\text { equipment }\end{array}$} & Yield losses & \multirow[t]{3}{*}{ Damage functions } \\
\hline & & & Rehabilitation tasks & \\
\hline & & & Damage to equipment & \\
\hline & M6: Coastal aquifers & $\begin{array}{l}\text { Drinking water } \\
\text { provision }\end{array}$ & Decrease in the service due to groundwater salinisation & Replacement costs \\
\hline
\end{tabular}


Table 2. Transition matrices of land-use change (in ha) from 2010 to 2100 for each scenario for the 58 municipalities under study. Numbers in brackets show percentage, which refers to the total area for each land-use category in 2010 (row). Text in bold shows major differences between adaptation options.

3 (a) Denial

\begin{tabular}{|c|c|c|c|c|c|c|c|c|c|}
\hline \multirow[b]{2}{*}{2010} & \multicolumn{8}{|c|}{2100} & \multirow[b]{2}{*}{ Total 2010} \\
\hline & Urban & Agriculture & $\begin{array}{l}\text { Beaches and } \\
\text { dunes }\end{array}$ & $\begin{array}{l}\text { Forests and } \\
\text { semi-natural }\end{array}$ & Lagoons & Wetlands & $\begin{array}{c}\text { Urban } \\
\text { wasteland }\end{array}$ & Sea & \\
\hline Urban & $20,536(87)$ & - & - & - & - & - & 3,050 (13) & - & 23,586 \\
\hline Agriculture & $3,050(3)$ & $81,050(90)$ & $447(1)$ & - & - & $4,602(5)$ & - & $751(1)$ & 89,900 \\
\hline Beaches and dunes & - & - & $2,052(62)$ & - & - & - & - & $1,256(38)$ & 3,307 \\
\hline Forests and semi-natural & - & - & $447(1)$ & 34,995 (93) & $663(2)$ & - & - & $1,640(4)$ & 37,745 \\
\hline Lagoons & - & - & - & - & $31,500(100)$ & - & - & - & 31,500 \\
\hline Wetlands & - & - & - & - & $1,067(6)$ & $18,036(94)$ & - & - & 19,103 \\
\hline Total 2100 & 23,586 & 81,050 & 2,946 & 34,995 & 33,230 & 22,638 & 3,050 & 3,647 & 205,141 \\
\hline Total transition (ha) & - & $-8,850$ & -362 & $-2,750$ & $+1,730$ & $+3,535$ & $+3,050$ & $+3,647$ & \\
\hline Total transition (\%) & - & -10 & -11 & -7 & +5 & +19 & +++ & +++ & \\
\hline
\end{tabular}

4

(b) "Laissez-faire"

\begin{tabular}{|c|c|c|c|c|c|c|c|c|c|}
\hline \multirow[b]{2}{*}{2010} & & \multirow[b]{2}{*}{ Total 2010} \\
\hline & Urban & Agriculture & $\begin{array}{c}\text { Beaches and } \\
\text { dunes }\end{array}$ & $\begin{array}{l}\text { Forests and } \\
\text { semi-natural }\end{array}$ & Lagoons & Wetlands & $\begin{array}{c}\text { Urban } \\
\text { wasteland }\end{array}$ & Sea & \\
\hline Urban & $20,536(87)$ & - & - & - & - & - & 3,050 (13) & - & 23,586 \\
\hline Agriculture & $3,050(3)$ & $81,050(90)$ & $447(1)$ & - & - & $4,602(5)$ & - & $751(1)$ & 89,900 \\
\hline Beaches and dunes & - & - & $1,842(56)$ & - & - & - & - & $1,466(44)$ & 3,307 \\
\hline Forests and semi-natural & - & - & $447(1)$ & 34,995 (93) & $663(2)$ & - & - & $1,640(4)$ & 37,745 \\
\hline Lagoons & - & - & - & - & $31,500(100)$ & - & - & - & 31,500 \\
\hline Wetlands & - & - & - & - & $1,067(6)$ & $18,036(94)$ & - & - & 19,103 \\
\hline Total 2100 & 23,586 & 81,050 & 2,736 & 34,995 & 33,230 & 22,638 & 3,050 & 3,857 & 205,141 \\
\hline Total transition (ha) & - & $-8,850$ & -572 & $-2,750$ & $+1,730$ & $+3,535$ & $+3,050$ & $+3,857$ & \\
\hline Total transition (\%) & - & -10 & -17 & -7 & +5 & +19 & +++ & +++ & \\
\hline
\end{tabular}

5 
Hérivaux et al. (2018) Regional Environmental Change (2018). https://doi.org/10.1007/s10113-018-1313-y

(c) Retreat

\begin{tabular}{|c|c|c|c|c|c|c|c|c|c|}
\hline \multirow[b]{2}{*}{2010} & \multicolumn{8}{|c|}{2100} & \multirow[b]{2}{*}{ Total 2010} \\
\hline & Urban & Agriculture & $\begin{array}{c}\text { Beaches and } \\
\text { dunes }\end{array}$ & $\begin{array}{l}\text { Forests and } \\
\text { semi-natural }\end{array}$ & Lagoons & Wetlands & $\begin{array}{c}\text { Urban } \\
\text { wasteland }\end{array}$ & Sea & \\
\hline Urban & $20,536(87)$ & - & $362(2)$ & - & - & 2,107 (9) & - & $582(2)$ & 23,586 \\
\hline Agriculture & $3,050(3)$ & $81,050(90)$ & $447(1)$ & - & - & $4,602(5)$ & - & $751(1)$ & 89,900 \\
\hline Beaches and dunes & - & - & $2,052(62)$ & - & - & - & - & $1,256(38)$ & 3,307 \\
\hline Forests and semi-natural & - & - & $447(1)$ & 34,995 (93) & $663(2)$ & - & - & $1,640(4)$ & 37,745 \\
\hline Lagoons & - & - & - & - & $31,500(100)$ & - & - & - & 31,500 \\
\hline Wetlands & - & - & - & - & $1,067(6)$ & $18,036(94)$ & - & - & 19,103 \\
\hline Total 2100 & 23,586 & 81,050 & 3,308 & 34,995 & 33,230 & 24,745 & - & 4,228 & 205,141 \\
\hline Total transition (ha) & - & $-8,850$ & 0 & $-2,750$ & $+1,730$ & $+5,642$ & - & $+4,228$ & \\
\hline Total transition (\%) & - & -10 & 0 & -7 & +5 & +30 & - & +++ & \\
\hline
\end{tabular}

2 
1 Second, these land-use changes will lead to major physical and economic impacts (Table 3). Economic impacts

2 are expected to reach $€ 19.5$ billion in the case of Denial, with more than 80,000 people forced to migrate and

3 relocate. The "cost of inaction" due to PF and RF represents on average $€ 43,000$ per inhabitant in 2010 , or $€ 140$

4 million $/ \mathrm{km}$ of coastline. Major impacts are expected from housing losses ( $80 \%$ of the total) and losses of beaches

5 and dunes (15\% of the total). This cost could be reduced by $50 \%$, if SLR was anticipated by economic agents

6 ("Laissez-faire"), and by 99\%, if public adaptation options were planned in advance (Protection and Retreat),

7 without considering adaptation costs. Negative SLR impacts on ecosystems are estimated at $€ 3$ billion in the Denial scenario ( $15 \%$ of the total) and could reach $€ 4.7$ billion in the "Laissez-faire" scenario ( $48 \%$ of the total). Total

9 SLR impacts on ecosystems are positive in the Retreat scenario, as beaches, dunes and wetlands are expected to evolve in an unconstrained way and their total area would increase as a result of the coastal topography. In addition, damage caused by an EF event that occurs in 2100 at the regional scale is expected to be $48 \%$ higher with SLR ( $€ 39.6$ billion in the Denial scenario) than without ( $€ 26.7$ billion) (Table 3$)$. The exposed population is expected to be $63 \%$ higher (70,000 people in the Denial scenario with SLR compared to 43,000 without SLR). The "cost of inaction" in case of EF is, thus, estimated at $€ 12.9$ billion ( $€ 29,000 /$ inhabitant or $€ 56$ million $/ \mathrm{km})$. This cost could be reduced by $91 \%$ if the Retreat option was implemented. In the Protection scenario, if protection efforts fail, economic impacts could be four times higher than without SLR (€104.6 billion). 
Hérivaux et al. (2018) Regional Environmental Change (2018). https://doi.org/10.1007/s10113-018-1313-y

Table 3. SLR impacts due to progressive PF and RF between 2010 and 2100, and in case of EF in 2100, for each scenario

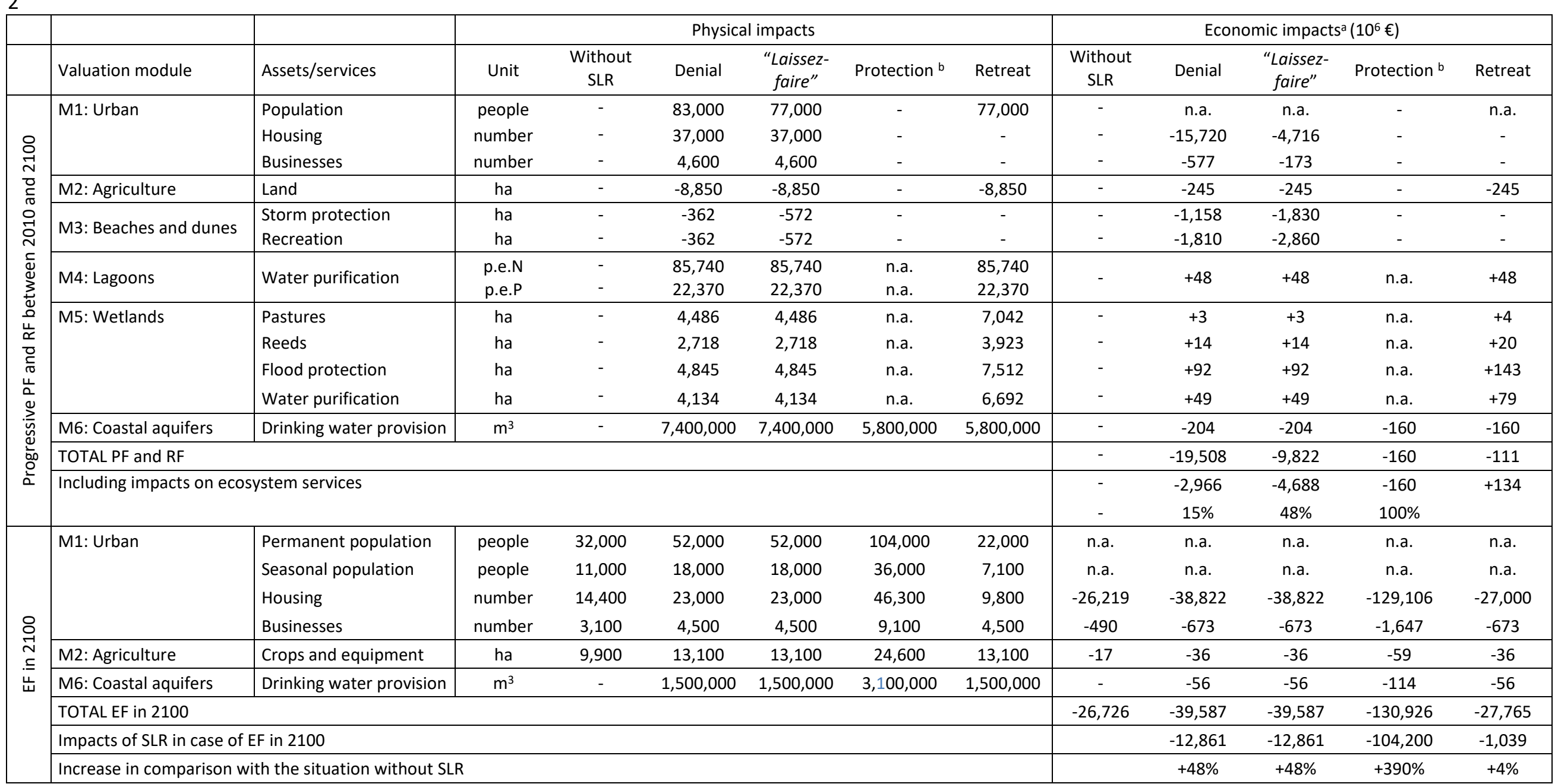

3 Note: n.a.: not assessed; p.e.N: person equivalent nitrogen; p.e.P.: person equivalent phosphorous

4 a Economic impacts are not discounted and measured in constant 2010 euros; ${ }^{b}$ For EF: in case protection works fail 
1

\section{2}

3

\section{DISCUSSION}

\subsection{The benefits of anticipating and adapting}

These results can be used to assess the benefits of anticipating and adapting to SLR for the 2010-2100 period. By comparing the Retreat and Denial scenarios, the total benefits of public adaptation planned in advance could amount to $€ 31.2$ billion ( $€ 19.4$ and $€ 11.8$ billion due to $P F / R F$ and $E F$, respectively), i.e. $€ 69,000$ per inhabitant of the study area in 2010 or $€ 135$ million/km of coastline. These figures highlight the importance of raising awareness levels of public services and coastal managers to SLR, in order to limit the damage caused by SLR. The effects of SLR will emerge slowly from 2040 onwards and then accelerate after 2080, given the topography of the study area: the current generation of managers and decision-makers may deny the existence of the risk. Nevertheless, some decisions have to be taken early and the need to conduct research on new technologies and economic instruments is immediate.

Anticipating and adapting to SLR may also carry high social and economic costs, depending on the option, which should be compared to the benefits. Examples of adaptation measures in Languedoc-Roussillon provide some cost estimates for the Protection and Retreat scenarios. However, further research is necessary in order to assess the costs of adaptation at a regional level:

- The first beach nourishment in the region was implemented in 2008 in the Aigues-Mortes Gulf, on $10 \mathrm{~km}$ of beaches. The initial cost was $€ 8.7$ million and the cost of maintenance is $€ 1$ million every 10 years. We estimate that similar large-scale beach nourishment would cost around $€ 253$ million, if it was implemented along the full $161 \mathrm{~km}$ of beaches in the region. A regional study conducted by CETE Méditerranée (2010) provides estimates of the costs for protecting the regional coastline from increasing erosion with a combination of measures outlined in the retreat scenario, as well as soft and hard protection measures. Total costs are estimated at $€ 351$ million at the 2040 time horizon. If extrapolated to the 2100 time horizon, they could reach at least $€ 1$ billion.

- To our knowledge, there are no examples of strategic, anticipatory and planned large-scale relocation for developed structures and activities, which could serve as a basis for assessing the cost of implementing the Retreat scenario. In the Languedoc-Roussillon region, in 2010, a road was relocated (strategic retreat) along $12 \mathrm{~km}$ of coastline between Sète and Marseillan, at a total cost of $€ 55$ million. This adaptation measure would cost $€ 545$ million if all the roads along the entire length $(70 \mathrm{~km})$ of Languedoc-Roussillon's natural beaches were relocated. However, this example is not representative of urban areas, where built assets (houses, apartments, business premises) would have to be relocated. André et al (2016) have designed an economic 
assessment based on a fictional site that constitutes an archetypal seaside community on the French Mediterranean coast. It represents a dense urban area with individual houses and apartments, as well as touristrelated businesses, located on a low-lying, sandy coastline and exposed to the risk of erosion and coastal flooding. They estimate that the full relocation of 650 inhabitants would cost between $€ 62$ and $€ 150$ million ( $€ 100,000$ to 231,000 per relocated inhabitant). Based on these figures, we estimate that the relocation of all urban areas in zones exposed to PF and RF (77,000 inhabitants) would cost between $€ 7.7$ and $€ 17.8$ billion.

Other criteria should also be incorporated into the decision-making, such as sustainability, equity (Clément et al. 2015) and affordability (Fletcher et al. 2016). For instance, the sustainability of massive beach nourishment, assumed to be carried out in the Protection scenario, could be called into question: maintenance measures should be conducted at 10 year intervals in order to reshape the beaches; locating and sustainably managing a reserve of sand is problematic. In our analysis, the Retreat scenario appears to be the best scenario for ecosystems. However, it also raises several issues, including solidarity between local councils: the risk of coastal flooding may potentially affect large areas in some municipalities, who lack sufficient land to relocate their population, housing and economic activities. At the regional scale, four municipalities with a total of 62,000 inhabitants would face this problem.

\subsection{The weight of coastal ecosystem services}

Our results underline the importance of incorporating coastal ecosystems into the assessment of adaptation scenarios. First, neglecting coastal ecosystems in the design of adaptation options may lead to the decrease and/or degradation of some ecosystem services as a result of marine flooding and coastal squeeze (loss of $44 \%$ of beach areas in the "Laissez-faire" scenario). In coastal areas, such as the Languedoc-Roussillon region, the potential negative economic impacts associated to these changes in ecosystem services are considerable: they represent $48 \%$ of the total economic impacts in the "Laissez-faire" scenario. Local residents, day trippers and tourist activities may also be affected by these changes. The valuation of impacts on wetlands also shows that, although the extension of wetland areas is expected to generate positive economic benefits in each adaptation scenario, they are maximal in the Retreat scenario. Thus, classic cost-benefit analyses used to rank alternative adaptation options may underestimate the benefits associated to adaptation in some situations because, in general, they do not account for ecosystem services. Second, some coastal ecosystems could play a key role in reducing the vulnerability of coastal communities in the event of marine flooding and storms. In our study area, we show that maintaining beaches and dunes, by avoiding coastal squeeze, is a valuable preventive measure that is likely to reduce the need 
for expensive engineering works in some locations (Spalding et al. 2014). However, it is not common practice for public services, coastal managers and engineering companies to incorporate ecosystem services in the economic valuation framework. A stepwise knowledge-sharing process should be set up before the integration of ecosystem services in the policy decision-making framework can be envisaged. Further research should also be conducted to improve our understanding of the impact of SLR on coastal ecosystems (groundwater, beaches and dunes, lagoons and wetlands) and to develop ecosystem-based adaptation strategies.

\subsection{An introduction to foresight approaches}

The four adaptation scenarios considered in this article are theoretical. We consider that the implementation of adaptation options is uniform along the regional coastline. However, in practice, adaptation is place- and contextspecific (Field et al. 2014): adaptation options are likely to consist of a spatial and temporal policy mix. Our narrative scenarios and the principal quantitative results of the economic impact analysis were used to introduce a 1-day foresight workshop held in June 2012, entitled "What coastline for the 2010-2050 Languedoc-Roussillon?" (Montpellier, France). The workshop was organised by the regional authorities and brought together 105 regional experts and stakeholders. Participants were organised into three groups and were asked to adapt and combine various options in order to build plausible adaptation pathways at the regional scale. The resulting scenarios involved two types of combination of "Laissez-faire" and Retreat scenarios: (i) the "organised Laissez-faire" or "voluntary Retreat" implements both options simultaneously; and (ii) the "two-step Retreat", which implements the "Laissez-faire" scenario first and then the Retreat scenario, as a way to make the Retreat scenario more acceptable. The same approach could be implemented locally (in groups of municipalities). This would probably lead to different combinations of approaches, which would depend on the local environmental, as well as the economic and social contexts, not to mention the outcomes of negotiations and compromise solutions.

\section{CONCLUSION}

Major land-use changes are expected due to SLR at the 2100 time horizon: relocation or densification of urban areas, loss of agricultural land, increase in lagoon areas and modification of wetlands (losses, migration or extension). The total benefit of public adaptation options that are planned in advance could reach $€ 31.2$ billion, i.e. $€ 69,000$ per inhabitant of the study area in 2010 or $€ 135$ million $/ \mathrm{km}$ of coastline. This valuation is obviously not exhaustive (many ecosystem services and damage to infrastructure are not valued). Therefore, our results should be considered as lower bound estimates. Our findings highlight the importance of (i) raising awareness to 
ensure that public services and coastal managers can anticipate the consequences of SLR and (ii) incorporating coastal ecosystems into the assessment of the adaptation options. They may be used as an aid for participatory foresight approaches. They could help public services and coastal managers anticipate and plan proactively for SLR: by identifying the ecosystems, coastal populations, infrastructure, agriculture and water resources that should be relocated due to the impacts of SLR; by identifying potential future conflicts among municipalities (for instance caused by the decrease in the availability and/or supply of land and water resources); and by raising awareness of the impacts of SLR on coastal natural habitats and municipalities. Further research is required to develop legal, governance and economic tools that could be used to implement adaptation. An analysis of the feasibility and acceptability of the different options for the local population and decision-makers is also essential.

Acknowledgments: This research was undertaken in the framework of the research project "Marine Inundation Hazard Exposure Modelling and Social, Economic and Environmental Vulnerability Assessment in regard to Global Changes" (MISEEVA), which was financed by the French National Research Agency. We gratefully acknowledge Jean-Daniel Rinaudo for his useful comments and suggestions. The preparatory work for this chapter was made possible thanks to financial support from BRGM.

\section{References}

Agenais A (2010) Evaluation économique des dommages liés à la submersion marine sur l'agriculture: Construction d'un modèle et application au Languedoc-Roussillon. Dissertation Montpellier SupAgro Brgm, Montpellier, France.

André C, Boulet D, Rey-Valette H, Rulleau B (2016) Protection by hard defence structures or relocation of assets exposed to coastal risks: Contributions and drawbacks of cost-benefit analysis for long-term adaptation choices to climate change. Ocean \& Coastal Management 134:173-182 doi: https://doi.org/10.1016/j.ocecoaman.2016.10.003

Anthoff D, Nicholls R, Tol R (2010) The economic impact of substantial sea-level rise. Mitigation and Adaptation Strategies for Global Change 15:321-335. doi : 10.1007/s11027-010-9220-7

Brunel C (2010) Evolution séculaire de l'avant côte de la Méditerranée française. Impact de l'élévation du niveau de la mer et des tempêtes. Thesis, Université Marseille 1, France. 
Hérivaux et al. (2018) Regional Environmental Change (2018). https://doi.org/10.1007/s10113-018-1313-y

Castaings J (2008) Etat de l'art des connaissances du phénomène de comblement des milieux lagunaires. Rapport de phase 1. Dissertation, Cépralmar, France. http://www.cepralmar.org/documents/etat-de-1-art-desconnaissances-du-phenomene-de-comblement-des-milieux-lagunaires/Etude_comblement_lagunes.pdf

Cépralmar (2006) Défi eutrophisation des lagunes littorales du Languedoc-Roussillon. Etude réalisée dans le cadre du 8ème programme de l'Agence de l'Eau Rhône-Méditerranée et Corse. http://www.cepralmar.org/documents/defi-eutrophisation-des-lagunes-littorales-du-languedocroussillon/Rapport_defi_lagunes.pdf

CETE Méditerranée (2010) Evaluation des coûts de protection des territoires littoraux en Languedoc-Roussillon. Rapport d'étude pour la DREAL Languedoc-Roussillon.

Clément V, Rey-Valette H, Rulleau B (2015) Perceptions on equity and responsibility in coastal zone policies. Ecol Econ 119:284-291. doi:10.1016/j.ecolecon.2015.09.005

CGDD (2010) Evaluation économique des services rendus par les zones humides. Etudes \& Documents n²3. http://www.developpement-durable.gouv.fr/IMG/pdf/ED23c-2.pdf

Craft C, Clough J, Ehman J, Joye S, Park R, Pennings S, Guo H, Machmuller M (2009) Forecasting the effects of accelerated sea-level rise on tidal marsh ecosystem services. Frontiers in Ecology and the Environment 7:73-78. doi: 10.1890/070219

Darwin RF, Tol RSJ (2001) Estimates of the Economic Effects of Sea Level Rise. Environmental and Resource Economics 19:113-129. doi : 10.1023/A:1011136417375

Deleuze C, Fotre C, Nuti I, Pierot F, Torterotot J (1991) Evaluation de fonctions de coûts économiques des dommages aux cultures dus aux inondations. Dissertation, Ecole Nationale du Génie Rural, des Eaux et des Forêts (ENGREF), Paris, France

Devaux-Ros C (2000) Evaluation des enjeux et des dommages potentiels liés aux inondations en Loire moyenne, Méthode et principaux résultats. Agence de l’Eau Loire-Bretagne, Orléans, France.

Fankhauser S (1994) Protection vs. retreat: estimating the costs of sea level rise, CSERGE Working Paper GEC 94-02. http://research.fit.edu/sealevelriselibrary/documents/doc_mgr/470/Global_Protection_vs_Retreat_SLR Cost_Estimation__Frankhauser_1994.pdf

Field CB, Barros VR, Mach KJ, Mastrandrea MD, van Aalst M, Adger WN, Arent DJ, Barnett J, Betts R, Bilir TE, Birkmann J, Carmin J, Chadee DD, Challinor AJ, Chatterjee M, Cramer W, Davidson DJ, Estrada YO, Gattuso JP, Hijioka Y, Hoegh-Guldberg O, Huang HQ, Insarov GE, Jones RN, Kovats RS, Romero- 
Lankao P, Larsen JN, Losada IJ, Marengo JA, McLean RF, Mearns LO, Mechler R, Morton JF, Niang I, Oki T, Olwoch JM, Opondo M, Poloczanska ES, Pörtner HO, Redsteer MH, Reisinger A, Revi A, Schmidt DN, Shaw MR, Solecki W, Stone DA, Stone JMR, Strzepek KM, Suarez AG, Tschakert P, Valentini R, Vicuña S, Villamizar A, Vincent KE, Warren R, White LL, Wilbanks TJ, Wong PP, Yohe GW (2014) Technical summary. In: Climate Change 2014: Impacts, Adaptation, and Vulnerability. Part A: Global and Sectoral Aspects. Contribution of Working Group II to the Fifth Assessment Report of the Intergovernmental Panel on Climate Change [Field, C.B., V.R. Barros, D.J. Dokken, K.J. Mach, M.D. Mastrandrea, T.E. Bilir, M. Chatterjee, K.L. Ebi, Y.O. Estrada, R.C. Genova, B. Girma, E.S. Kissel, A.N. Levy, S. MacCracken, P.R. Mastrandrea, and L.L. White (eds.)]. Cambridge University Press, Cambridge, United Kingdom and New York, NY, USA, pp. 35-94.

Fletcher CS, Rambaldi AN, Lipkin F, McAllister RRJ (2016) Economic, equitable, and affordable adaptations to protect coastal settlements against storm surge inundation. Regional Environmental Change 16:10231034. doi: 10.1007/s10113-015-0814-1

Ghyben BW, Drabbe J (1889) Nota in verband met de voorgenomen putboring nabij Amsterdam (Notes on the probable results of the proposed well drilling near Amsterdam). Tijdschrift van het Koninklijk Institunt voor Ingenieurs, The Hague:8-22

Hallegatte S, Ranger N, Mestre O, Dumas P, Corfee-Morlot J, Herweijer C, Wood RM (2011) Assessing climate change impacts, sea level rise and storm surge risk in port cities: a case study on Copenhagen. Clim Change 104:113-137. doi: 10.1007/s10584-010-9978-3

Herzberg A (1901) Die Wasserversorgung einiger Nordseebaden (The water supply on parts of the North Sea coast in Germany). Zeitung für Gasbeleuchtung und Wasserversorgung 44:815-9-842-4

Hinkel J, van Vuuren DP, Nicholls RJ, Klein RJT (2013) The effects of adaptation and mitigation on coastal flood impacts during the 21st century. An application of the DIVA and IMAGE models. Clim Change 117:783794. doi : 10.1007/s10584-012-0564-8

IIBRBS (1998) Evaluation des dommages liés aux crues en Région Ile de France. Agence de l'Eau SeineNormandie, Nanterre, France.

Ifremer (2001) L'eutrophisation des eaux marines et saumâtres en Europe, en particulier en France. Rapport Ifremer pour la Commission Européenne - DG.ENV.B1. 64p. 
Hérivaux et al. (2018) Regional Environmental Change (2018). https://doi.org/10.1007/s10113-018-1313-y

Kebede AS, Nicholls RJ (2012) Exposure and vulnerability to climate extremes: population and asset exposure to coastal flooding in Dar es Salaam, Tanzania. Regional Environmental Change 12:81-94. doi: $10.1007 / \mathrm{s} 10113-011-0239-4$

Kuhfuss L, Rey-Valette H, Sourisseau E, Heurtefeux H, Rufray X (2016) Evaluating the impacts of sea level rise on coastal wetlands in Languedoc-Roussillon, France. Environ Sci \& Policy 59:26-34. doi:10.1016/j.envsci.2016.02.002

Lecacheux S, Pedreros R, Devallée E, Poisson B, Garcin M (2010) Evaluation simplifiée de la submersion marine à l'échelle du Languedoc-Roussillon. Rapport du projet ANR MISEEVA. BRGM, Orléans, France.

Li S, Meng X, Ge Z, Zhang L (2015) Vulnerability assessment of the coastal mangrove ecosystems in Guangxi, China, to sea-level rise. Regional Environmental Change 15:265-275. doi: 10.1007/s10113-014-0639-3

Lichter M, Felsenstein D (2012) Assessing the costs of sea-level rise and extreme flooding at the local level: A GIS-based approach. Ocean Coast Manage 59:47-62. doi: 10.1016/j.ocecoaman.2011.12.020

Lin BB, Khoo YB, Inman M, Wang C, Tapsuwan S, Wang X (2014) Assessing inundation damage and timing of adaptation: sea level rise and the complexities of land use in coastal communities. Mitigation Adapt Strat Global Change 19:551-568. doi: 10.1007/s11027-013-9448-0

Luisetti T, Turner K, Bateman IJ (2008) An ecosystem services approach to assess managed realignment coastal policy in England. CSERGE Working Paper ECM 08-04. Norwich: University of East Anglia. http://www.cserge.ac.uk/sites/default/files/ecm_2008_04.pdf

MEA (2005) Millenium Ecological Assessment. Millennium Ecosystem and Human Well-being: A framework for Assessment. Washington, DC:Island Press.

MEDDTL (2012) Stratégie nationale de gestion intégrée du trait de côte. Vers la relocalisation des activités et des biens. Paris, France. http://www.developpement-durable.gouv.fr/IMG/pdf/12004_Strategie-gestion-traitde-cote-2012_DEF_18-06-12_light.pdf

Michael JA (2007) Episodic flooding and the cost of sea-level rise. Ecol Econ 63:149-159. doi: 10.1016/j.ecolecon.2006.10.009

Monioudi IN, Karditsa A, Chatzipavlis A, Alexandrakis G, Andreadis OP, Velegrakis AF, Poulos SE, Ghionis G, Petrakis S, Sifnioti D, Hasiotis T, Lipakis M, Kampanis N, Karambas T, Marinos E (2014) Assessment of vulnerability of the eastern Cretan beaches (Greece) to sea level rise. Regional Environmental Change:1-12. doi: 10.1007/s10113-014-0730-9 
Nicholls RJ, Wong PP, Burkett VR, Codignotto JO, Hay JE, McLean RF, Ragoonaden,S and Woodroffe C (2007) Coastal systems and low-lying areas. In: Climate Change 2007: Impacts, Adaptation and Vulnerability. Contribution of Working Group II to the Fourth Assessment Report of the Intergovernmental Panel on Climate Change, [Parry, M.L., O.F. Canziani, J.P. Palutikof, P.J. van der Linden, and C.E. Hanson (eds.)]. Cambridge University Press, Cambridge, UK and New York, NY, USA, pp. 315-356.

Oude Essink GHP (2001) Improving fresh groundwater supply—problems and solutions. Ocean Coast Manage 44:429-449. doi: 10.1016/S0964-5691(01)00057-6

Rulleau B, Rey-Valette H, Hérivaux C (2015) Valuing welfare impacts of climate change in coastal areas: a French case study. J Environ Plann Manage 58:482-494. doi: 10.1080/09640568.2013.862492

Rulleau B, Rey-Valette H (2013) Valuing the benefits of beach protection measures in the face of climate change: a French case-study. Journal of Environmental Economics and Policy 2:133-147. doi : $10.1080 / 21606544.2013 .776213$

Sogreah (2011) Rapport sur l'évaluation économique des dommages liés à l'élévation du niveau de la mer sur l'habitat et les entreprises à l'échelle régionale. Projet MISEEVA. Grenoble, France.

Spalding MD, Ruffo S, Lacambra C, Meliane I, Hale LZ, Shepard CC, Beck MW (2014) The role of ecosystems in coastal protection: Adapting to climate change and coastal hazards. Ocean Coast Manage 90:50-57. doi : 10.1016/j.ocecoaman.2013.09.007

SYMADREM (2010) Etude du renforcement de la digue du Rhône rive droite entre Beaucaire et Fourques: Etude des enjeux agricoles. Chambre d'agriculture du Gard, Nîmes, France.

Titus JG (1990) Greenhouse effect, sea level rise and land use. Land Use Policy 7:138-153. doi: 10.1016/02648377(90)90005-J

Tompkins, EL, Few, R, Brown, K (2008). Scenario-based stakeholder engagement: Incorporating stakeholders preferences into coastal planning for climate change, Journal of Environment Management 88, 15801592. doi: 10.1016/j.jenvman.2007.07.025.

Torterotot JF (1993) Le coût des dommages liés aux inondations: estimation et analyse des incertitudes, Thesis ENPC Paris/ Marne-la-Vallée, France.

UNEP-MAP, RAC/SPA (2010) The Mediterranean Sea Biodiversity: state of the ecosystems, pressures, impacts and future priorities. By Bazairi, H., Ben Haj, S., Boero, F., Cebrian, D., De Juan, S., Limam, A., Lleonart, J., Torchia, G., and Rais, C., Ed. RAC/SPA, Tunis; 100p. 
Hérivaux et al. (2018) Regional Environmental Change (2018). https://doi.org/10.1007/s10113-018-1313-y

Vanroye C, Auffret C (2010) Coût de la protection côtière en Languedoc-Roussillon: Quelle rentabilité? in Actes des journées "Impact du Changement Climatique sur les Risques Côtiers", 15-16th November 2010, Orléans, France. http://www.brgm.fr/sites/default/files/risques_cotiers_2010_actes.pdf

Wong PP, Losada IJ, Gattuso JP, Hinkel J, Khattabi A, McInnes KL, Saito Y, Sallenger A (2014): Coastal systems and low-lying areas. In: Climate Change 2014: Impacts, Adaptation, and Vulnerability. Part A: Global and Sectoral Aspects. Contribution of Working Group II to the Fifth Assessment Report of the Intergovernmental Panel on Climate Change [Field, C.B., V.R. Barros, D.J. Dokken, K.J. Mach, M.D. Mastrandrea, T.E. Bilir, M. Chatterjee, K.L. Ebi, Y.O. Estrada, R.C. Genova, B. Girma, E.S. Kissel, A.N. Levy, S. MacCracken, P.R. Mastrandrea, and L.L. White (eds.)]. Cambridge University Press, Cambridge, United Kingdom and New York, NY, USA, pp. 361-409.

Yohe G, Neumann J, Marshall P, Ameden H (1996) The economic cost of greenhouse-induced sea-level rise for developed property in the United States. Climatic Change 32:387-410. doi: 10.1007/BF00140353

Yohe G, Neumann J, Ameden H (1995) Assessing the Economic Cost of Greenhouse-Induced Sea Level Rise: Methods and Application in Support of a National Survey. J Environ Econ Manage 29:S78-S97. doi: 10.1006/jeem.1995.1062

Yohe G (1990) The Cost of Not Holding Back the Sea - Toward a National Sample of Economic Vulnerability. Coast Manage 18:403-431. doi: 10.1080/08920759009362123

Zhou Y, Tol RSJ (2005) Evaluating the costs of desalination and water transport. Water Resour Res 41: W03003. doi: 10.1029/2004WR003749 
Hérivaux et al. (2018) Regional Environmental Change (2018). https://doi.org/10.1007/s10113-018-1313-y

1 Electronic supplementary material

2 ESM_1. Details on the valuation functions per module

3 ESM_2. Schematic representation of the four adaptation scenarios for the coastal area 